\title{
Effects of Liming on Soil Physical Attributes: A Review
}

\author{
Elio Conradi Junior ${ }^{1}$, Affonso Celso Gonçalves $\mathrm{Jr}^{1}$, Edleusa Pereira Seidel ${ }^{1}$, Guilherme Lindner Ziemer ${ }^{1}$, \\ Juliano Zimmermann ${ }^{1}$, Vinícius Henrique Dias de Oliveira ${ }^{1}$, Daniel Schwantes ${ }^{2} \&$ Carlos Daniel Zeni ${ }^{1}$ \\ ${ }^{1}$ State University of Western Paraná, Marechal Cândido Rondon, State of Paraná, Brazil \\ ${ }^{2}$ Departamento de Ciencias Vegetales, Facultad de Agronomía e Ing. Forestal, Pontificia Universidad Católica de \\ Chile, Santiago, Chile \\ Correspondence: Elio Conradi Junior, Center of Agricultural Sciences, State University of Western Paraná, \\ Pernambuco Street, 1777, Centro, 85960-000, Marechal Cândido Rondon, Paraná, Brazil. E-mail: \\ elio.conradi@outlook.com
}

Received: March 29, 2020

doi:10.5539/jas.v12n10p278
Accepted: August 21, $2020 \quad$ Online Published: September 15, 2020

URL: https://doi.org/10.5539/jas.v12n10p278

\begin{abstract}
The objective of the present study was to gather information on the effects of liming on changes in soil physical attributes. Soil acidity, caused by natural ways, such as rain, weathering and decomposition of organic matter and by human interference, by the use of nitrogen fertilizer mainly ammonia and urea fertilizer contribute to the acidification of the soil. In this context liming is perform to correct soil $\mathrm{pH}$ and neutralize the effect of toxic elements. Numerous benefits of liming are known, but their influence on soil physical attributes is poorly studied. Liming directly affects some physical properties of the soil, such as flocculation, aggregates, density and porosity. Flocculation of soil particles initially is smallest, which promotes greater particle dispersion. However, it changes over time, since $\mathrm{H}^{+}$and $\mathrm{Al}^{3+}$ ions tend to be subsumed by $\mathrm{Ca}^{2+}$ and $\mathrm{Mg}^{2+}$ increasing particle flocculation power which favors its approximation and aggregate formation. For soil aggregates, surface liming in improves soil aggregation by increasing the mean aggregate diameter with positive responses as dose increases. Density and porosity of soil also undergo changes. It is important to point out that liming also has the potential to alter the porous structure of the soil. Porosity liming promotes soil density reduction and increase influenced reducing macroporosity values and increase of total porosity and micropores values. The results of studies carried out present divergent and similar results according to the evaluated physical attributes. This is possibly due to the dynamics between liming under different edaphoclimatic conditions.
\end{abstract}

Keywords: soil physical properties, improvement of soil attributes, soil management

\section{Introduction}

The great demand in food production worldwide demands more and more from soil management to obtain high agricultural productivity in order to ensure food security. The growing acidification of soils because of agricultural activity has become a major environmental concern in recent years (Kryzevicius et al., 2019). Faced with the necessity of intensive agricultural production and together with sustainable management it is necessary to build the soil fertility. This construction seeks chemical, physical and biological improvements.

In this context, the liming technique is a fundamental tool. It is a technique in which calcium and magnesium are applied, mainly carbonates, oxides, hydroxides or a mixture of these, in addition to silicates that can also be used, but less frequently. The objective of this technique is to reduce the protons concentration in acidic soils (Bortolanza \& Klein, 2016; Miller et al., 1995). The liming requirement can be defined as the amount of corrective material necessary to obtain the maximum economic efficiency of a crop, which would mean having defined quantities of $\mathrm{Ca}^{2+}$ and $\mathrm{Mg}^{2+}$ available in soil and adequate $\mathrm{pH}$ conditions to have a good availability of nutrients (Dechen et al., 2006).

Soils can be naturally acidic due to the poverty of the source material in calcium, magnesium, potassium and sodium, which are the exchangeable bases of soil or the intensity of weathering processes resulting in higher levels of hydrogen and aluminum in the soil exchange complex and, consequently, also in the soil solution (Sousa et al., 2018). However, the process of agricultural exploitation is also a factor that generates soil acidity, either through exportation, leaching of soil nutrients (exchangeable bases) and intensification of organic matter 
cycle in soil; in addition, the application of nitrogen fertilizers with an acidifying effect. This form of soil acidification is call anthropic influence (Raij, 2011).

The liming is an agricultural practice capable of altering chemical, physical and biological soil, providing a number of benefits. It promotes a decrease in soil acidity, insolubilization of toxic elements, mainly aluminum and manganese; increase calcium and magnesium levels and phosphorus and molybdenum availability (Ronquin, 2010). Besides, it favors the development of microorganisms present in soil and enables greater root system development, expanding the plants' capacity to absorb water and nutrients from soil.

However, in addition to changes in the chemical and biological attributes of soil, the practice of liming also results changes in the physical attributes. These effects depend on the interaction of several factor such as climate, soil class and intrinsic characteristics of each soil. Several researches have already studied the physical changes resulting from use of limestone demonstrating its influence on flocculation of soil particles (Spera et al., 2008), formation and stability of aggregates (Ferreira et al., 2019), density (Spera et al., 2008; Auler et al., 2017), porosity (Anikwe et al., 2016; Ferreira et al., 2019) and penetration resistance (Stenberg et al., 2000). The results of these changes reflects on other factors, presenting indirect effects: root development (Bomfim-Silva et al., 2019), microbiological activity (Stenberg et al., 2000; Børja \& Nielsen, 2009), nutrients availability (Malavolta, 1980; Cahyono et al., 2019), crop yield (Zandoná et al., 2015) and content of organic matter of soil (Passos et al., 2019).

Due to the diversified dynamics that liming can present in different edaphoclimatic conditions, this review article aims to contribute with information about the liming effects on physical properties of soil.

\section{Soil Acidity}

Soil acidity is one of the main factors that limit the growth and productivity of many crops, especially in most of tropical and subtropical regions. In this context, it is important to understand its nature in order to perform the correct soil management. It should be considered different forms of acidity: active and potential.

The active acidity related to amount of $\mathrm{H}^{+}$dissolved in soil solution. The activity of this ion is express by $\mathrm{pH}$, defined as a cologarithm of $\mathrm{H}^{+}$activity in solution. A correlation is observed between the concentration of $\mathrm{H}^{+}$in soil solution and its $\mathrm{pH}$, the higher $\mathrm{H}^{+}$content the lower $\mathrm{pH}$.

Potential acidity is related to soil resilience in having its $\mathrm{pH}$ changed when basic compounds are added. This is divided into exchangeable and non-exchangeable acidity. The exchangeable acidity refers to ions $\mathrm{Al}^{3+}$ and $\mathrm{H}^{+}$ retained on the surface of soil colloids. This amount of exchangeable $\mathrm{H}^{+}$is small. Therefore, only exchangeable $\mathrm{Al}^{3+}$ is allow. The non-exchangeable acidity is the $\mathrm{H}^{+}$ion of covalent bond associated to negatively charged colloids and aluminum compounds. The acidity soils show when $\mathrm{pH}$ is below 5.5. Above $\mathrm{pH} 5.5$, there is no more exchangeable $\mathrm{Al}^{3+}$.

The potential acidity is the sum of exchangeable and non-exchangeable acidity. It limits the roots growth and occupies spaces in colloids, allowing free nutrients in soil solution to be leached (Bissani et al., 2008).

\section{Soil Acidification}

\subsection{Natural Causes}

Some factors affecting soil $\mathrm{pH}$ such as climate, mineral content and soil texture cannot be changed. Soils may naturally have acidity depending on the source material and climatic conditions to which it is exposed. Generally, the acidification started or get emphasis from the removal of basic elements $\left(\mathrm{Ca}^{2+}, \mathrm{Mg}^{2+}, \mathrm{K}^{+}\right.$and $\left.\mathrm{Na}^{+}\right)$of colloids soil combined with a reduce rate of release by weathering.

The in rainwater contributes to the input of $\mathrm{H}^{+}$ions, which occurs by the partial dissolution of carbonic gas from atmosphere: $\mathrm{CO}_{2}+\mathrm{H}_{2} \mathrm{O} \Leftrightarrow \mathrm{HCO}_{3}^{-}+\mathrm{H}^{+}$, releasing $\mathrm{HCO}_{3}$ and $\mathrm{H}^{+}$. In turn, $\mathrm{H}^{+}$releases an exchangeable cation in solid phase of soil. This exchangeable cation is leach with $\mathrm{HCO}_{3}$. This contributes to increasing the acidity of soil. The lower $\mathrm{pH}$ of soil the greater concentration of $\mathrm{H}^{+}$ions (Gliński et al., 2011; Bissani et al., 2008).

The decomposition of organic matter by microorganisms also supports the increase in soil acidity due to organic and inorganic acids formed during the decomposition of soil organic matter, plant residues and soil biota (Gliński et al., 2011; Bissani et al., 2008).

Another factor that contributes to acidification of soils is the weathering of minerals and the dissociation of organic acids (Van Breemen et al., 1983; Fujii et al., 2012). 


\subsection{Human Causes}

In addition to environmental causes, human actions can also contribute to soil acidification. The application of nitrogen fertilizer contributes to soil acidification, since the use of ammoniacal fertilizer and urea requires a process of nitrogen transformation, called nitrification, which is carry out through the action of bacteria (Nitrosomonas; Nitrobacter). In this process, hydrogen ions are release, which contribute to reducing the soil $\mathrm{pH}$. Another source of rising soil acidity is the occurrence of acid rain, resulting from anthropic interference. Due to the gases emission, mainly $\mathrm{SO}_{2}$ and $\mathrm{NO}_{\mathrm{x}}$ from the combustion of fossil fuels, nitric and sulfuric acids are formed that reach the soil through precipitation (Gliński et al., 2011).

\subsection{Limestone Reactions in Soil}

After application, the limestone applied undergoes reactions in soil. The applied calcium and magnesium oxides, carbonates and silicates promote an increase in soil $\mathrm{pH}$, by reducing acidity. $\mathrm{A} \mathrm{Ca}^{2+}$ ion from limestone replaces two $\mathrm{H}^{+}$ions at the exchange sites present in soil. Carbon dioxide $\left(\mathrm{CO}_{2}\right)$ can react with water and form carbon acid $\left(\mathrm{H}_{2} \mathrm{CO}_{3}\right)$. Protons are neutralized by hydroxyls $\mathrm{OH}^{-}$and water is formed. The alteration in soil $\mathrm{pH}$ occur due to the transformation of hydrogen ions into water and carbon dioxide $\left(\mathrm{CO}_{2}\right)$ and insolubilization of aluminum since it is transform into hydroxide (Gliński et al., 2011) as can be observed through the reactions present below.

(a) Solubilization and dissociation of limestone:

$$
\begin{aligned}
& \mathrm{CaCO}_{3} \text { (insoluble) }+\mathrm{H}_{2} \mathrm{O} \rightarrow \mathrm{Ca}^{2+}+\mathrm{HCO}_{3}^{-}+\mathrm{OH}^{-} \text {(soluble) } \\
& \mathrm{MgCO}_{3} \text { (insoluble) }+\mathrm{H}_{2} \mathrm{O} \rightarrow \mathrm{Mg}^{2+}+\mathrm{HCO}_{3}^{-}+\mathrm{OH}^{-} \text {(soluble) } \\
& \mathrm{CaO} \text { (insoluble) }+\mathrm{H}_{2} \mathrm{O} \rightarrow \mathrm{Ca}^{2+}+2 \mathrm{OH}^{-} \text {(soluble) } \\
& \mathrm{MgO} \text { (insoluble) }+\mathrm{H}_{2} \mathrm{O} \rightarrow \mathrm{Mg}^{2+}+2 \mathrm{OH}^{-} \text {(soluble) }
\end{aligned}
$$

(b) Neutralization of acids in soil:

$\mathrm{HCO}_{3}{ }^{-}+\mathrm{H}^{+} \rightarrow \mathrm{CO}_{2}+\mathrm{H}_{2} \mathrm{O}$

$\mathrm{H}^{+}+\mathrm{OH}^{-} \rightarrow \mathrm{H}_{2} \mathrm{O}$

(c) Insolubilization of toxic aluminum exchangeable in soil:

$$
\mathrm{Al}^{3+} \text { (soluble) }+3 \mathrm{OH}^{-} \rightarrow \mathrm{Al}(\mathrm{OH})_{3} \text { (insoluble) }
$$

With the application of limestone, the exchangeable aluminum is neutralized, increasing base saturation (V\%). With the neutralization of part of adsorbed hydrogen, the $\mathrm{pH}$ of soil increases. In order to occur the limestone reaction, it must be mix well with the substrate, remaining in contact with all particles. In addition, it is important that soil is moist in order to solubilize the limestone (Ronquin, 2010).

\section{Liming Effects on Soil Physical Attributes}

\subsection{Flocculation}

The liming has ability to change the chemical composition of soil. Depending the dose used and its characteristics, it may change the physical aspects. Among the modified properties, the particle flocculation should be highlight since it is influence by the changes in concentration of ions present in soil.

Flocculation is the process that soil clay particles come together in stable granules. Unlike crystallization, where atoms or molecules form strong structures, in the flocculation the bonds between the particles are weak, due to the compounds that intermediate the bond between the molecules (Benoot et al., 2019).

Due to the flocculation process, the clays treated with limestone have different granulometric distributions, considerably reducing the amount of fine particles, as these interact with the limestone and flocculate, being able to aggregate into larger particles, which are reasonably stable even under subsequent flooding (Gupta et al., 2019).

The importance of lipotropic series must be highlight. The exchangeable elements in soil present different binding energies when it interacts with colloids according to the charge and the size of hydrated ion (Yamada and Roberts, 2005). The lyotropic series in a simplified way is a logical sequence, in which there is an interaction between element and soil, following a relationship from highest to lowest energy: $\mathrm{H}^{+}>>>>\mathrm{Al}^{+3}>\mathrm{Ca}^{+2}>\mathrm{Mg}^{+2}>$ $\mathrm{NH}^{+4} \sim \mathrm{K}^{+}>\mathrm{Na}^{+}$.

After the solubilization and dissolution of limestone, occurs a precipitation of $\mathrm{Al}^{3+}$ and neutralization of $\mathrm{H}^{+}$, in addition to an increase in the content of $\mathrm{Ca}^{2+}$ causing alteration of lyotropic sequence. Therefore, different 
reactions can happen after the liming. The clay dispersion can occur due to a greater repulsion between soil particles by an increase in negative net charge and thickness of diffuse double electric later, caused by the replacement of $\mathrm{Al}^{3+}$ by $\mathrm{Ca}^{2+}$ and $\mathrm{Mg}^{2+}$ (Fontes et al., 1995). It is observed in soils with a low point of zero charge (PZC) that have less buffering power in relation to the change in $\mathrm{pH}$ (Figure 1).
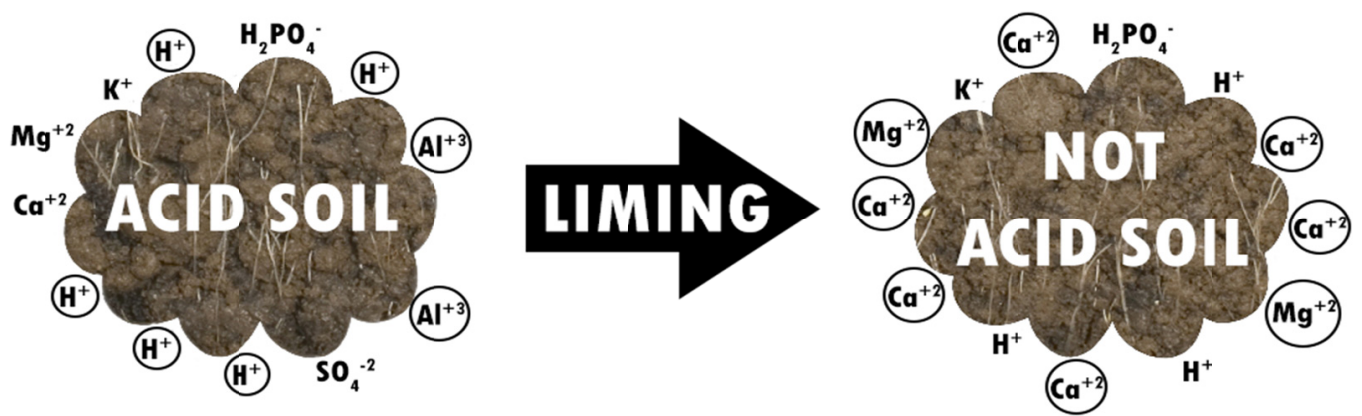

Figure 1. Ionic substitution in soil colloids before and after liming

Source: the author.

The interactions resulting from the application of limestone, present different dynamics according to soil type. Ferralsols, e.g., present initial aggregation in the form of granules, microaggregates, stable and naturally resistant. However, the neutralization of exchangeable $\mathrm{Al}^{3+}$, which stabilizes the soil structure and raises the $\mathrm{pH}$, it contributes to the dispersion of soil into unitary particles (Reis et al., 2019). Therefore, it is possible to infer that in soils of variable charge as the case of most tropical soils. The application of limestone to neutralize $\mathrm{Al}^{3+}$ and $\mathrm{H}^{+}$, initially occurs less flocculation, which changes with the time, since the tendency is for these ions to be replaced by $\mathrm{Ca}^{2+}$ and $\mathrm{Mg}^{2+}$ ions in soil colloids, which keeps the soil particles flocculated, despite having less valence in the pyotropic series.

Studies have been carried out with the objective of evaluating the interaction between liming and its interference with soil particle flocculation. Bortoluzzi et al. (2008) concluded that liming directly influences soil particles and bonding sites, promoting changes in charge and increase dispersion. However, Spera et al. (2008) reported that the dispersion of clay increases until the incubation of $50 \%$ of the limestone dose $\left(3.8 \mathrm{Mg} \mathrm{ha}^{-1}\right)$ necessary to raise the soil acidity to $\mathrm{pH}$ 6.0. In addition, a decrease in flocculation was also observed. According to Machado et al. (2017), a greater dispersion of clay was observed after 12 months of incubation in treatments with doses of 1.46 and $2.73 \mathrm{Mg} \mathrm{ha}^{-1}$ of dolomitic limestone in relation to the control in Red Ferralsols. Limestone with a high content of $\mathrm{Ca}$ and $\mathrm{Mg}$ tend to be more dispersive (Machado et al., 2017). The use of limestone to raise the base saturation to $100 \%$ in different types of use provides lowest values of flocculation degree in soil evaluated 45 days after application (Junior et al., 2006).

The liming effects on the clays flocculation can be affected by the limestone application. Auler et al. (2017), observed significant differences in clay flocculation between soils subjected to liming in surface or incorporated $(0-10 \mathrm{~cm})$. In the treatment in which the limestone was applied to the surface without incorporation, the flocculation was significantly lower, when compared to the limestone incorporated in soil. The authors attributed the lower flocculation of clays in unincorporated soil to the preservation of soil macroaggregates, as well as surfaces coated with $\mathrm{Ca}^{2+}$. Under these conditions, due to soil structure, clays do not flocculate and, consequently, do not form new microaggregates and remain dispersed in soil.

The limestone application can cause changes in soil microstructure in the short term. According to Tran et al. (2014), using the scanning electron microscopy (SEM) technique it is possible to observe the occurrence of flocculation only seven days after limestone treatment. Similarly, Jha and Sivapullaiah (2019) showed the microstructural alteration of soil after limestone application in the same time period as the previous study, portraying its quickly effect on the soil physical properties.

The increase in $\mathrm{Ca}$ cations from the dissociation of $\mathrm{Ca}$ carbonate occurs coagulation of organic and mineral colloids from soil, promoting their flocculation (Gliński et al., 2011). Muneer and Oades (1989) report that liming causes $\mathrm{Ca}^{2+}$ to be a predominant cation in the exchange complex, acting as a physical stabilizer of soil organic matter since it allows for better particle flocculation. The promotion of colloid flocculation, in turn, corroborates other physical effects resulting from liming, such as the aggregates formation. 


\subsection{Aggregates}

Liming performed in order to correct soil acidity can alter the mechanisms of flocculation, formation and stabilizations of macro and microaggregates (Bronick \& Lal, 2005; Six et al., 2004). The aggregates are components of soil structure and the aggregation process is the result of approximation and cementation of organic and mineral particles in soil. According to Duiker et al. (2003) is the result of rearrangement of particles, flocculation and cementation of microstructures and microaggregates. This is a process, which depends on the total organic carbon content, biota, ionic bound, clay and carbonates (Bronick \& Lal, 2005).

Aggregates are extremely important for obtaining quality soil. It is essential for maintaining soil porosity and aeration, plant growth and microbial population, water infiltration and control of erosion processes (Oades, 1984). Note that the presence of chemical elements minerals such as calcium and magnesium assist the process of aggregates formation and increase stability, coupled with other factors such as secretion of organic compounds at roots. In tropical soils, cementation results mainly from organic matter and from the action and metabolism of living organisms on this organic matter, generating aggregating substances.

The influence of liming on aggregates formation is another aspect to be highlight. The dissociation of calcium ions in soil after application of limestone promotes an increase in the content of this element directly and indirectly. In addition, the correction of soil $\mathrm{pH}$ due to the neutralizing power of hydroxyls $(\mathrm{OH})$, promotes the reduction of acidity and elevation of $\mathrm{pH}$, thus increasing the availability of various nutrients, including calcium.

This ion has an important action on the formation and stability of aggregates. For the aggregate formation, it is necessary that soil colloids are flocculated and that all components of the aggregate are subsequently stabilized by some cementing agent (Hillel, 1980). The flocculation and subsequent particle aggregation occur within a few hours after limestone application (Babu \& Poulose, 2018). In this context, $\mathrm{Ca}^{2+}$ acts as a binding agent between the organic and mineral fraction of soil, favoring the association and strengthening the links between mineral and organic particles, favoring the aggregates formation (Gliński et al., 2011). A fact that is explain by the high correlation between levels of total organic carbon and $\mathrm{Ca}^{2+}$ (Briedis et al., 2012), as elucidated in Figure 2.

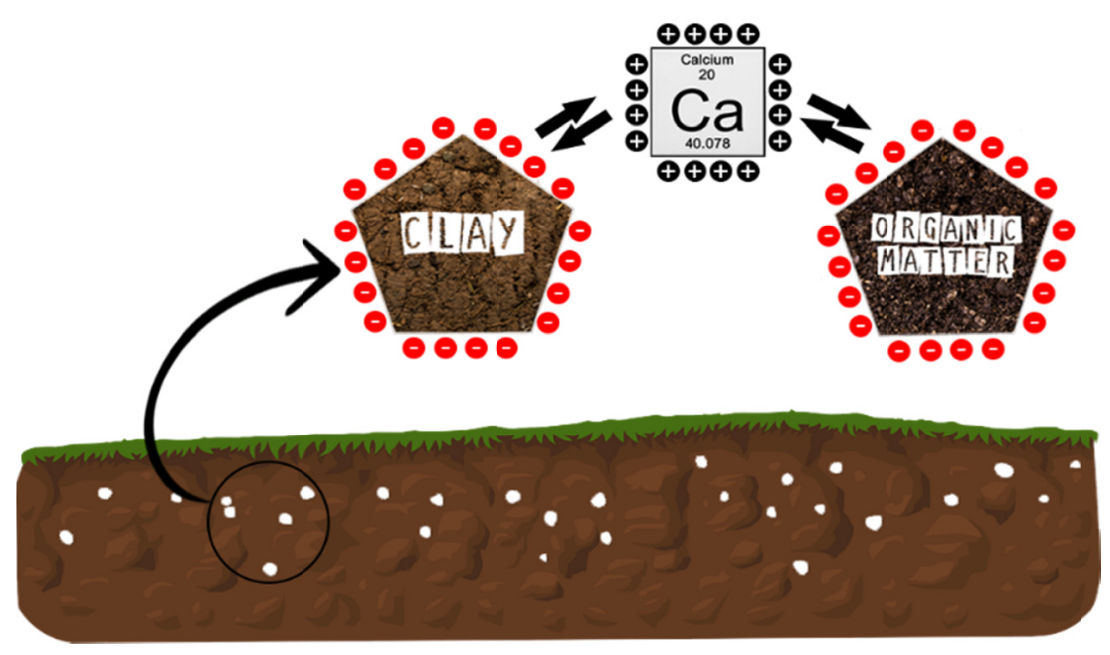

Figure 2. Importance of calcium increase and its action as a binding agent in the aggregates formation

Source: the author.

Positive interaction between the liming and aggregates have been report in the bibliography. According to Briedis et al. (2012), the $\mathrm{Ca}^{2+}$ derived by liming surface present correlation with the contents of total organic carbon and acting as a cation bridge between the surfaces of clay particles and carbon organic soil. The surface liming under no-till system improves soil aggregation by increasing the average aggregate diameter in the layer $(0-0.01 \mathrm{~m})$, but without the same effect on the layer $(0.02-0.1 \mathrm{~m})$ (Ferreira et al., 2019). However, in a study by Carmeis Filho et al. (2018), the superficial liming in no-till system increased the amount of soil macroaggregates at a depth of 0-0.4 m, but the effect magnitude varied according to the applied limestone dose and soil depth. Further, the increase in average aggregate diameter show a positive correlation according to the increase in applied limestone doses. In addition to the direct effect of calcium on soil aggregation, the correction of acidity can have indirect effects on soil properties, since the production of area and root phytomass of the crops 
increases the content of soil organic matter and microbial activity. These factors favor soil aggregation (Corrêa et al., 2009). Changes in soil aggregation due to liming, in turn, modify other physical properties of soil, such as density and porosity.

\subsection{Density}

Soil density is defined as the relationship between the mass of a soil sample dried at $105{ }^{\circ} \mathrm{C}$ and the sum of volumes occupied by particles and pores. Depending on the physical and chemical changes resulting from limestone use, density can also change.

According to Auler et al. (2017) by means of linear correlation for analysis for superficial application of limestone without overturning in relation to the control, in treatments on layer of 0 to $0.10 \mathrm{~m}$, was detected significant interaction, demonstrating an increase in soil $\mathrm{pH}$, clay dispersed in water, contents of $\mathrm{Ca}^{2+}$ and $\mathrm{Mg}^{2+}$ promoting a reduction in soil density.

In contrast, Spera et al. (2008) obtained different values of soil density in layers of 0-0.05 $\mathrm{m}$ to $0.015-0.020 \mathrm{~m}$, and in the layer of $0.015-0.020 \mathrm{~m}$ an increase in density values was observed in proportion to the dose used, while in layer of $0-0.05 \mathrm{~m}$ the density values remained similar.

Carneis Filho et al. (2016) carried out a work in Oxisols on a tropical region. The trial consisted of four treatments: a control with no soil amendment application, application of $2.1 \mathrm{Mg}^{-1}$ phosphogypsum, application of $2.0 \mathrm{Mg} \mathrm{ha}^{-1}$ limestone and application of limestone + phosphogypsum $\left(2.0+2.1 \mathrm{Mg} \mathrm{h}{ }^{-1}\right.$, respectively). The results showed both soil amendments applied together reduced soil bulk density by up to $16 \%$ and penetration resistance in subsurface soil layers, what can be explained by increase observed in the aggregate size class resulted in a better organization of soil particles and increasing of macroporosity.

According to Ribeiro et al. (2007), changes in density and porosity of soil are related. Therefore, it is important to note that liming also has a potential for altering the porosity of soil.

\subsection{Porosity}

The soil pores are represented by cavities of different sizes and shapes, determined by the arrangement of solid particles and constitute the volumetric fraction of soil occupied with air and solution (water and nutrients).

The quantity and quality of soil porosity represents great importance in the development of crops. This physical attribute interferes with aeration, infiltration, drainage and water retention and soil temperature, directly related to the development and productivity of crops (Hiel et al., 2016).

The effects of liming on soil porosity are also the subject of this review. According to Auler et al. (2017) the linear correlation analysis for surface application of limestone without inversion and the control, in layer of 0 to $0.10 \mathrm{~m}$ showed significant interaction. The $\mathrm{pH}$ increased in soil, dispersed clay in water and levels of $\mathrm{Ca}^{2+}$ and $\mathrm{Mg}^{2+}$, as well as promote a reduction on soil density, also influenced by reducing values of macroporosity and an increase in values of total porosity and micropores.

Alternatively, Spera et al. (2008), when studying the effects of liming in columns with samples of a dystrophic Red Ferralsols observed that there was a difference in the dynamics between used limestone doses and macro and micropores. In addition, a difference was verified in the depths evaluated $(0-0.05 \mathrm{~m})$ and $(0.015-0.020 \mathrm{~m})$. According to the study, from the dose of $7.6 \mathrm{Mg} \mathrm{ha}^{-1}$ was observed stabilization of change on different physical attributes. In relation to micropores, the reduction was observed in both studied layers. However, in relation to macropores, a significant reduction was found in layer of $0.015-0.020 \mathrm{~m}$, while in the layer of 0-0.05 $\mathrm{m}$ no changes were observed.

Carmeis Filho et al. (2018) conducted a study on tropical long-term no-till soils. Four limestone rates $(0,1000$, 2000 , and $4000 \mathrm{~kg} \mathrm{ha}^{-1}$ ) were used by surface application. The results show liming at a rate of $2000 \mathrm{~kg} \mathrm{ha}^{-1}$ has influenced positively the total porosity and macroporosity in the deepest soil layers $(0.20-0.40$ and $0.40-0.60 \mathrm{~m})$. According to the authors, the study results evidences that liming is an essential tool for maintenance and sustainability of conservationist system.

A study carried out by Auler et al. (2017) evaluating surface and incorporated liming. The treatments were three application modes (on the surface, incorporated via plowing and incorporated via subsoiling and harrowing), with and without $15 \mathrm{Mg} \mathrm{ha}^{-1}$ of limestone. Eighteen months after application, undisturbed and disturbed soil samples were collected from the $0-0.10$ and $0.10-0.20$ m layers. According to the study, liming promoted an increase in micro and macroporosity and contributing to the availability of water and soil aeration on both layers. 
Liming might affect the soil structure in positive or negative ways (Haynes and Naidu 1998; Bronick and Lal, 2005). However, according to the studies shown in this review, liming normally improve some physical properties of soils, as porosity.

Soil acidity is one of the most important constraints in crop production in temperate as well as tropical regions of the world. Liming is an important practice to correct soil acidity in order to maintain or increase soil fertility within sustainable management in the context of current agriculture. The effects on the physical attributes of soil are diverse and, in some situations, present contradictory results according to the characteristics of each study. However, it is also observed significant lack of studies on the impact of setting the physical properties and structural soil condition. Future studies need to be conducted under different edaphoclimatic conditions in order to contribute with such information. In addition, it is important to consider recent changes in the rotations of the main crops. In general, the effects of liming can be explained by the flocculation and cementing action of $\mathrm{Ca}^{2+}$ are probably the dominant mechanisms in the short term. In the long term, increases in productivity induced by liming, result in greater input of organic material, accumulation of organic matter and biological activity of soil, both favoring the stability of aggregates and improvement of other physical attributes.

\section{References}

Anikwe, M. A. N., Eze, J. C., \& Ibudialo, A. N. (2016). Influence of lime and gypsum application on soil properties and yield of cassava (Manihot esculenta Crantz.) in a degraded Ultisol in Agbani, Enugu Southeastern Nigeria. Soil \& Tillage Res., 158, 32-38. https://doi.org/10.1016/j.still.2015.10.011

Auler, A. C., Pires, L. F., Santos, J. A. B., Caires, E. F., Borges, J. A. R., \& Giarola, N. F. B. (2017). Effects of surface - applied and soil - incorporated lime on some physical attributes of a Dystrudept soil. Soil Use Manag., 33, 129-410. https://doi.org/10.1111/sum.12330

Bissani, C. A., Gianelo, C., Camargo, F. A. O., \& Tedesco, M. J. (2008). Fertilidade dos solos e manejo da adubação de culturas (2nd ed.). Editora Metrópole, Porto Alegre.

Bomfim-Silva, E. M., Costa, A. S., José, J. V., Ferraz, A. P. F., Damasceno, A. P. A. B., \& Silva, T. J. A. (2019). Correction of Acidity of a Brazilian Cerrado Oxisol with Limestone and Wood Ash on the Initial Growth of Cowpea. Agric. Sci., 10, 841-851. https://doi.org/10.4236/as.2019.107064

Børja, I., \& Nilsen, P. (2008). Long term effect of liming and fertilization on ectomycorrhizal colonization and tree growth in old Scots pine (Pinus sylvestris L.) stands. Plant Soil, 314, 109-119. https://doi.org/ 10.1007/s11104-008-9710-5

Bortolaza, D. R., \& Klein, V. A. (2016). Soil Chemical and Physical Properties on an Inceptisol after Liming (Surface and Incorporated) Associated with Gypsum Application. Rev. Bras. Ciênc. Solo., 40. https://doi.org/10.1590/18069657rbcs20150377

Bortoluzzi, E. C., Garbozza, L., Guareschi, C., \& Rheinheimer, D. S. (2008). Effects of liming on the relationship between soil and water. Rev. Bras. Ciênc. Solo., 32, 261-2628. https://doi.org/10.1590/ S0100-06832008000700003

Briedis, C., Moraes Sá, J. C., Caires, E. F., Navarro, J. F., Inagaki, T. M., Boer, A., ... Santos, J. B. (2012). Soil organic matter pools and carbon-protection mechanisms in aggregate classes influenced by surface liming in a no-till system. Geoderma, 170, 80-88. https://doi.org/10.1016/j.geoderma.2011.10.011

Bronick, C. J., \& Lal, R. (2005). Soil structure and management: A review. Geoderma, 124, 3-22. https://doi.org/ 10.1016/j.geoderma.2004.03.005

Cahyono, P., Loekito, S., Wiharso, D., Afandi, R. A., Nishimura, N., Noda, K., \& Masateru, S. (2019). Influence of Liming on Soil Chemical Properties and Plant Growth of Pineapple (Ananas Comusus L.Merr.) On Red Acid Soil, Lampung, Indonesia. Commun. Soil Sci. Plant Anal., 50, 2797-2803. https://doi.org/10.1080/ 00103624.2019.1671441

Corrêa, J. C., Bull, L. T., Crusciol, C. A. C., \& Moraes, M. H. (2009). Oxisol physical attributes affected by surface application of flue dust, aqueous lime, sewage sludges and limestone. Rev. Bras. Ciênc. Solo., 33, 263-272. https://doi.org/10.1590/S0100-06832009000200004

Dechen, A. R., Fernandes, M. S., \& Nachtigall, G. R. (2006). Micronutrientes. In M. S. Fernandes (Eds.), Nutrição Mineral de Plantas (pp. 323-343). Sociedade Brasileira de Ciência do Solo, Minas Gerais.

Duiker, S. W., Rhoton, F. E., Torrent, J., Smeck, N. E., \& Lal, R. (2003). Iron (Hydr)Oxide Crystallinity Effects on Soil Aggregation. Soil Sci. Soc. Am. J., 67, 606-611. https://doi.org/ 10.2136/sssaj2003.6060 
Ferreira, T. R., Pires, L. F., Wildenschild, D., Brinatti, A. M., Borges, J. A. R., Auler, A. C., \& Reis, A. M. H. (2019). Lime application effects on soil aggregate properties: Use of the mean weight diameter and synchrotron-based X-ray $\mu \mathrm{CT}$ techniques. Geoderma, 338, 585-596. https://doi.org/10.1016/j.geoderma. 2018.10.035

Fontes, M. P. F., Gjorup, G. B., Alvarenga, R. C., \& Nascif, P. G. S. (1995). Calcium Salts and Mechanical Stress Effects on Water-Dispersible Clay of Oxisols. Soil Sci. Soc. Am. J., 59, 224-227. https://doi.org/ 10.2136/sssaj1995.03615995005900010034x

Fujii, K., Aoki, M., \& Kitayama, K. (2012). Biodegradation of low molecular weight organic acids in rhizosphere soils from a tropical montane rain forest. Soil Biol. Biochem., 47, 142-148. https://doi.org/ 10.1016/j.soilbio.2011.12.018

Gliński, J., Horabik, J., \& Lipiec, J. (2011). Encyclopedia of Agrophysics (1st ed.). Springer, Heidelberg. https://doi.org/10.1007/978-90-481-3585-1

Hiel, M., Chélin, M., Parvin, N., Barbieux, S., Degrune, F., Lemtiri, A., ... Garré, S. (2016). Crop residue management in arable cropping systems under a temperate climate. Part 2: Soil physical properties and crop production: A review. Biotechnol. Agron. Soc. Environ., 20, 245-256. https://doi.org/10.25518/1780-4507. 12986

Hillel, D. (1980). Fundamentals of Soil Physics (1st ed.). Academic Press, New York. https://doi.org/10.1016/ B978-0-12-348580-9.50005-5

Junior, E. J. R., Martins, R. M. G., Rosa, Y. B. C. J., \& Cremon, C. (2006). Calcário e gesso como condicionante físico e químico de um solo de cerrado sob três sistemas de manejo. Pesqui. Agropecu. Trop., 36, 37-44. https://doi.org/10.5216/pat.v36i1.2170

Kryzevicius, Z., Karcauskiene, D., Álvarez-Rodríguez, E., Zukauskaite, A., Slepetiene, A., \& Volungevicius, J. (2019). The effect of over 50 years of liming on soil aluminium forms in a Retisol. J. Agric. Sci., 157, 1-8. https://doi.org/10.1017/S0021859619000194

Machado, W., Melo, T. R., \& Filho, J. T. (2017). Clay dispersion and loss in Oxisol treated with different concentrations of limestone. Semin. Cienc. Agrar., 38, 3907-3914. https://doi.org/10.5433/1679-0359. 2017v38n6p3907

Malavolta, E. (1980). Elementos de nutrição mineral das plantas (1st ed.). Agronômica Ceres, São Paulo.

Miller, J. D., Anderson, H. A., Harriman, R., \& Collen, P. (1995). The consequences of liming a highly acidified catchment in central Scotland. Water, Air, and Soil Pollut., 85, 1015-1020. https://doi.org/10.1007/ BF00476963

Muneer, M., \& Oades, J. M. (1989). The role of Ca-organic interactions in soil aggregate stability .III. Mechanisms and models. Aust. J. Soil Res., 27, 411-423. https://doi.org/10.1071/SR9890411

Oades, J. M. (1984). Soil organic matter and structural stability: Mechanisms and implications for management. Plant Soil, 76, 319-337. https://doi.org/10.1007/BF02205590

Passos, A. B. R. J., Souza, M. F., Saraiva, D. T., Silva, A. A., Queiroz, M. E. L. R., Carvalho, F. P., \& Silva, D. V. (2019). Effects of Liming and Urochloa brizantha Management on Leaching Potential of Picloram. Water, Air, and Soil Pollut., 230, 12. https://doi.org/10.1007\%2Fs11270-018-4062-0

Raij, B. V. (2011). Fertilidade do solo e manejo de nutrientes (1st ed.). International Plant Nutrition Institute, Piracicaba.

Reis, D. A., Portella, R. B., Fagundes, M. O., Júnior, F. R. F., Santos, J. R. S., Bogiani, J. C., \& Perina, F. J. (2019). Degree of dispersion, microbial biomass and organic carbon of an oxisol cultivated with soybean under conventional and no-tillage in the cerrado (savannah) of the west of Bahia, Brazil. Ibero-Amer. J. Environ. Sci. http://doi.org/10.6008/CBPC2179-6858.2019.001.0030

Ribeiro, K. D., Menezes, S. M., Mesquita, M. G. B. F., \& Sampaio, F. M. T. (2007). Soil physical properties, influenced by pores distribution, of six soil classes in the region of Lavras-MG. Ciênc. Agrotec., 31, 1167-1175. https://doi.org/10.1590/S1413-70542007000400033

Ronquin, C. C. (2010). Conceitos de fertilidade do solo e manejo adequado para as regiões tropicais (1st ed.). Embrapa Monitoramento por Satélite, Campinas. 
Six, J., Bossuyt, H., Degryze, S., \& Denef, K. (2004). A history of research on the link between (micro)aggregates, soil biota, and soil organic matter dynamics. Soil \& Tillage Res., 79, 7-31. https://doi.org/10.1016/j.still.2004.03.008

Sousa, E. A. B., Reis, I. M. S., Melém Júnior, N. J., Silva, L. S., Oliveira, I. A., \& Freitas, L. (2018). Quantificação de óxidos de ferro, atributos químicos e físicos dos solos em diferentes ecossistemas do estado do Amapá. In A. M. Zuffo \& J. G. Aguilera (Eds.), Solos nos biomas brasileiros (pp. 46-54). Atena, Ponta Grossa.

Spera, S. T., Denardin, J. E., Escosteguy, P. A. V., Santos, H. P., \& Figueroa, E. A. (2008). Clay dispersion in microaggregates of soil incubated with limestone. Rev. Bras. Ciênc. Solo., 32, 2613-2620. https://doi.org/ 10.1590/S0100-06832008000700002

Stenberg, M., Stenberg, B., \& Rydberg, T. (2000). Effects of reduced tillage and liming on microbial activity and soil properties in a weakly-structured soil. Appl. Soil Ecol., 14, 165-145. https://doi.org/10.1016/ S0929-1393(00)00043-3

Van Breemen, N., Mulder, J., \& Driscoll, C. T. (1983). Acidification and alkalinization of soils. Plant Soil, 75, 283-308. https://doi.org/10.1007/BF02369968

Yamada T., \& Roberts, T. L. (2005). Potássio na agricultura Brasileira (1st ed.). KP Potafos, Piracicaba.

Zandoná, R. R., Beutler, A. N., Burg, G. M., Barreto, C. F., \& Schmidt, M. R. (2015). Gypsum and lime increase soybean and maize yield and decrease drought stress. Pesqui, Agropecu. Trop., 45, 128-137. https://doi.org/10.1590/1983-40632015v4530301

\section{Copyrights}

Copyright for this article is retained by the author(s), with first publication rights granted to the journal.

This is an open-access article distributed under the terms and conditions of the Creative Commons Attribution license (http://creativecommons.org/licenses/by/4.0/). 